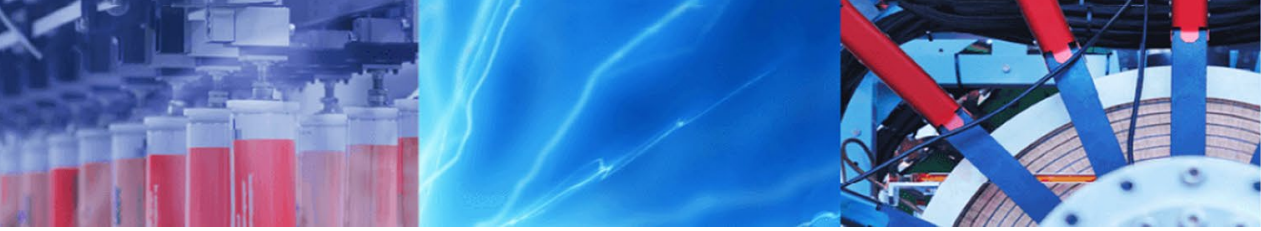

Research Article

\title{
Magnetic mesoporous silica/graphene oxide based molecularly imprinted polymers for fast selective separation of bovine hemoglobin
}

\author{
Haimei Xiao ${ }^{1} \cdot$ Lei Cai $^{1} \cdot$ Shan Chen ${ }^{1} \cdot$ Zhaohui Zhang $^{1,2,3}$
}

Received: 19 January 2020 / Accepted: 19 March 2020 / Published online: 26 March 2020

(c) Springer Nature Switzerland AG 2020

\begin{abstract}
In this work, a facile protein imprinted polymer based on magnetic rich-amine mesoporous silica/graphene oxide was synthesized using dopamine as the functional monomer and bovine hemoglobin as the template molecule. $\mathrm{Fe}_{3} \mathrm{O}_{4}$ nanoparticles were introduced onto graphene oxide by an inverse microemulsion method for facilitating surface polymerization dopamine imprinted layer. The protein adsorption test showed that the imprinted layer based on magnetic rich-amine mesoporous silica/graphene oxide can significantly shorten the adsorption equilibrium time of the imprinted polymer toward bovine hemoglobin. Under optimized conditions, the imprinting factor and maximum adsorption capacity of the magnetic imprinted polymer toward bovine hemoglobin was 2.09 and $164.5 \mathrm{mg} \mathrm{g}^{-1}$, respectively. Several experimental parameters including temperature and $\mathrm{pH}$ of solution, type and volume of elution solvent, washing solvent, extraction time were investigated in detail. Combined with magnetic solid phase extraction and high performance liquid chromatography, the magnetic imprinted polymers was successfully applied to rapid separate and enrich bovine hemoglobin from bovine serum with the recoveries of $84.6-102.5 \%$.
\end{abstract}

Keywords Magnetic solid phase extraction · Surface imprinting · Bovine hemoglobin · Graphene oxide · Magnetic mesoporous silica

\section{Introduction}

Molecular imprinting technology is a method to synthesis molecularly imprinted polymers (MIPs) which have the recognition sites complementary to the shape and functional groups of the template molecule [1]. With the advantages of easy synthesis, high selectivity and low cost, MIPs have been applied for selective recognition $[2,3]$, solid phase extraction [4,5], liquid chromatography [6-9], sensing [10, 11], catalysis, degradation and drug delivery [12]. Although the molecular imprinting in the field of small molecule was successful, the biomacromolecule including protein $[7,13]$, peptide [14], cell [15] and viruse [16] imprinting technique has been limited due to their large dimensions, chemical and structural complexity, slow mass transfer and environmental instability [17]. Certainly, a diversity of strategies such as surface imprinting [18, 19], epitope imprinting [20, 21], boronate affinity molecular imprinting [22] and microcontact imprinting have also been developed to overcome these limitations. Due to the recognition site was attached to the surface of material, surface imprinting has been proved as a prior strategy for improving the performance

Electronic supplementary material The online version of this article (https://doi.org/10.1007/s42452-020-2573-y) contains supplementary material, which is available to authorized users.

$\triangle$ Zhaohui Zhang, zhaohuizhang77@163.com | ${ }^{1}$ National Demonstration Center for Experimental Chemistry Education, College of Chemistry and Chemical Engineering, Jishou University, Jishou 416000, China. ${ }^{2}$ State Key Laboratory of Chemo/Biosensing and Chemometrics, Hunan University, Changsha 410082, China. ${ }^{3}$ Key Laboratory of Mineral Cleaner Production and Exploit of Green Functional Materials in Hunan Province, Jishou University, Jishou 416000, China. 
of biomacromolecule imprinted polymers. For example, Yan et al. [23] prepared a novel carbon nanotube based imprinted polymer for separation bovine serum albumin. Xie et al. [7] have successfully synthesized a photonic and magnetic dual responsive protein imprinted material for specific separation of bovine hemoglobin ( $\mathrm{BHb})$. Zhang et al. [24] prepared a novel imprinted polymer based on magnetic particle using itaconic acid and acrylamide as monomers.

In recent years, $\mathrm{Fe}_{3} \mathrm{O}_{4}$ particles $[5,12,13]$, graphene oxide (GO) [23], mesoporous silica particles [21, 25], and carbon tubes $[1,26]$ have been widely applied as the supporting substance for biomacromolecule imprinting. GO is a kind of two-dimensional carbon material that contains various oxygen-containing functional groups including hydroxyl, carboxyl, and epoxy groups, which help to graft of imprinted layer on the surface during the preparation of MIPs. However, GO tends to accumulate during the application due to the $\pi-\pi$ stacking interaction of the $\mathrm{GO}$ sheets.

Herein, a simple and facile way was developed to construct magnetic molecularly imprinted polymers (M-MIPs) for rapid specific selective separation of BHb. In this work, the M-MIPs were prepared with rich-amino mesoporous silica and $\mathrm{GO}$ hybrid composites $\left(\mathrm{Fe}_{3} \mathrm{O}_{4} @ \mathrm{SiO}_{2}-\mathrm{GO}\right)$ as the carriers, $\mathrm{BHb}$ as the template protein and dopamine as the functional monomer due to its ability to self-polymerize in an alkaline environment. The doped $\mathrm{Fe}_{3} \mathrm{O}_{4}$ can effectively increase the specific surface area of GO. Moreover, the $\mathrm{Fe}_{3} \mathrm{O}_{4}$ particles encapsulated with the imprinted layer resulted in the M-MIPs can be easily separated by applying an external magnetic field. The M-MIPs showed high adsorption capacity, excellent selectivity and good reproducibility. Combined with magnetic solid phase extraction (M-SPE) and high performance liquid chromatography (HPLC), the M-MIPs were successfully applied to rapid separate and enrich $\mathrm{BHb}$ from bovine serum.

\section{Experimental section}

\subsection{Materials and reagents}

Bovine hemoglobin (BHb, molecular mass $64.5 \mathrm{kDa}$, pl 6.9), human serum albumin (HSA, molecular mass $66.0 \mathrm{kDa}$, pl 5.6), bovine serum albumin (BSA, molecular mass $66.0 \mathrm{kDa}$, pl 4.9), and lysozyme (Lyz, molecular mass $14.4 \mathrm{kDa}$, pl 10.7) were purchased from Sigma-Aldrich. Tetraethoxysilane (TEOS) and 3-aminopropyltriethoxysilane (APTES) were purchased from Sigma-Aldrich (St. Louis, USA). GO was purchased from Tianjin Hengxing Chemical Reagent Co. Iron (III) chloride hexahydrate $\left(\mathrm{FeCl}_{3} \cdot 6 \mathrm{H}_{2} \mathrm{O}\right)$ was supplied by Guangfu Fine Chemical Research. 1-Ethyl-3-(3dimethylaminopropyl) carbodiimide (EDC), triton X-100 and $\mathrm{N}$-hydroxy succinimide (NHS) were purchased from Aladdin Reagent (Shanghai, China). Acetonitrile, acetic acid, hydrochloric acid, sulfuric acid, nitric acid, potassium permanganate, sodium dodecyl sulfate (SDS), dopamine (DA), 30\% hydrogen peroxide solution, ethanol (HPLC grade),hydrazine hydrate, and sodium citrate were obtained from Changsha Chemical Reagent Co (Hunan, China). All chemicals are of analytical grade, and doubledistilled water was used throughout this work.

\subsection{Analysis equipment}

The morphology of magnetic composites was characterized with scanning electron microscopy (SEM, Zeiss-Sigma HD, Germany) and transmission electron microscopy (TEM, FEI Tecnai G2 F20, USA). The magnetism of the composite was assessed with a vibrating sample magnetometer (VSM, M27407, Lake Shore Ltd.). Fourier-transform infrared spectroscopy (FT-IR, $4000-400 \mathrm{~cm}^{-1}$ ) was investigated by Nicolet iS10 Fourier-transform infrared (FT-IR) spectrometer (Thermo scientific, USA). The adsorption characteristics were determined with a UV spectrometer (UV2450, Shimadzu, Japan) and HPLC with an LC2010AHT solution system (Shimadzu, Japan). HPLC analysis was performed on a Spherigel $C_{18}$ column $(5 \mu \mathrm{m}, 250 \mathrm{~mm} \times 4.6 \mathrm{~mm})$. All solutions were filtered through a $0.45 \mu \mathrm{m}$ filter membrane before use. The mobile phase was a $50 \mathrm{mmol} \mathrm{L}^{-1}$ phosphate buffer solution $(\mathrm{pH} \mathrm{7.0)}$ with a flow rate of $0.5 \mathrm{~mL} \mathrm{~min}{ }^{-1}$. The inject sample volume was $10 \mu \mathrm{L}$, and proteins were detected through a UV detector at $406 \mathrm{~nm}$ (BHb), $278 \mathrm{~nm}$ (BSA), $281 \mathrm{~nm}$ (HSA), and $290 \mathrm{~nm}$ (Lyz).

\subsection{Preparation of M-MIPs}

\subsubsection{Preparation of amine functionalized magnetic mesoporous silica $\left(\mathrm{Fe}_{3} \mathrm{O}_{4} @ \mathrm{SiO}_{2}-\mathrm{NH}_{2}\right)$}

$\mathrm{Fe}_{3} \mathrm{O}_{4}$ nanoparticles were prepared by hydrothermal method. Firstly, $1.73 \mathrm{~g}$ of $\mathrm{FeCl}_{3} \cdot 6 \mathrm{H}_{2} \mathrm{O}$ was dissolved in $35 \mathrm{~mL}$ of ethylene glycol to form a clear solution. Then $3.6 \mathrm{~g}$ of $\mathrm{NaAc}$ was added under stirring for $30 \mathrm{~min}$. Sealed in a Teflon-lined stainless steel autoclave, the mixture was maintained at $200{ }^{\circ} \mathrm{C}$ for $10 \mathrm{~h}$. Cooled to room temperature, the black product was washed repeatedly with ethanol and dried under vacuum at $60^{\circ} \mathrm{C}$ to obtain $\mathrm{Fe}_{3} \mathrm{O}_{4}$ nanoparticles. $\mathrm{Fe}_{3} \mathrm{O}_{4} @ \mathrm{SiO}_{2}-\mathrm{NH}_{2}$ was prepared by a onepot method. Briefly, $25 \mathrm{~mL}$ of cyclohexanol, $50.5 \mathrm{~mL}$ of cyclohexane, $10 \mathrm{~mL}$ of triton $\mathrm{X}-100$, and $7.5 \mathrm{~mL}$ of water were mixed to form a water-in-oil reverse microemulsion. Then, $500 \mathrm{mg}$ of $\mathrm{Fe}_{3} \mathrm{O}_{4}$ nanoparticles was added into the system. After sonication for $30 \mathrm{~min}$, the mixture was stirred at room temperature for $3 \mathrm{~h}$. After that, $0.9 \mathrm{~mL}$ of ammonium hydroxide and $1.5 \mathrm{~mL}$ of TEOS were added into the 
solution under stirred for $12 \mathrm{~h}$. Added $0.5 \mathrm{~mL}$ of APTES, the mixture was kept at room temperature for another $12 \mathrm{~h}$. Finally, the precipitates were washed respectively with ethanol and double distilled water for 8 times, and then dried in a vacuum at $50^{\circ} \mathrm{C}$ for $24 \mathrm{~h}$.

\subsubsection{Preparation of $\mathrm{Fe}_{3} \mathrm{O}_{4} @ \mathrm{SiO}_{2}-\mathrm{GO}$}

$0.1 \mathrm{~g}$ of $\mathrm{GO}$ was dispersed in $50 \mathrm{~mL}$ of DMF under sonicated for $30 \mathrm{~min}$. Then $0.1 \mathrm{~g}$ of NHS and $0.2 \mathrm{~g}$ of EDC were added into the mixture under stirred at room temperature for $2 \mathrm{~h}$. After that, $0.5 \mathrm{~g}$ of $\mathrm{Fe}_{3} \mathrm{O}_{4} @ \mathrm{SiO}_{2}-\mathrm{NH}_{2}$ was added. After stirring for $3 \mathrm{~h}$, the product was washed with ethanol for 3 times. Finally, the product was dried in vacuum for $24 \mathrm{~h}$ at $50{ }^{\circ} \mathrm{C}$ to obtain magnetic graphene oxide/ mesoporous silica composite materials $\left(\mathrm{Fe}_{3} \mathrm{O}_{4} @ \mathrm{SiO}_{2}-\mathrm{GO}\right)$.

\subsubsection{Synthesis of M-MIPs}

Firstly, $250.0 \mathrm{mg}$ of $\mathrm{Fe}_{3} \mathrm{O}_{4} @ \mathrm{SiO}_{2}-\mathrm{GO}$ was dispersed in $100.0 \mathrm{~mL}$ of phosphate buffer solution $(\mathrm{pH}=8.0)$ by sonication for $15 \mathrm{~min}$. Next, $200.0 \mathrm{mg}$ of DA and $80.0 \mathrm{mg}$ of $\mathrm{BHb}$ were added. The mixture was stirred in the dark for $7.5 \mathrm{~h}$. Then the resultant composite was washed respectively with double distilled water and $\mathrm{NaOH}\left(0.1 \mathrm{~mol} \mathrm{~L}^{-1}\right)$ solution to remove the unreacted monomer and template. Finally, the M-MIPs were dried in vacuum at $50^{\circ} \mathrm{C}$ for $24 \mathrm{~h}$. Magnetic non-imprinted polymers based on $\mathrm{Fe}_{3} \mathrm{O}_{4} @ \mathrm{SiO}_{2}-$ GO (M-NIPs) were also prepared by the same synthesis method except that the template was not added in the preparation process.

\subsection{Protein adsorption experiment}

\subsubsection{Isothermal adsorption experiment}

In the isothermal adsorption assays, $5.0 \mathrm{mg}$ of M-MIPs (M-NIPs or $\mathrm{Fe}_{3} \mathrm{O}_{4} @ \mathrm{SiO}_{2}-\mathrm{GO}$ ) was added into the adsorption tube containing $10 \mathrm{~mL}$ of $\mathrm{BHb}$ solution with different concentrations ranged from 0.05 to $0.45 \mathrm{mg} \mathrm{mL}^{-1}(\mathrm{pH}=8.0$, $10 \mathrm{mM}$ PBS). After incubation for $12 \mathrm{~h}$, the supernatant (M-MIPs, M-NIPs or $\mathrm{Fe}_{3} \mathrm{O}_{4} @ \mathrm{SiO}_{2}-\mathrm{GO}$ ) was separated by an external magnetic field, and the concentration of protein was detected by UV-vis spectrophotometer at $406 \mathrm{~nm}$. The adsorption capacity $\left(\mathrm{Q}, \mathrm{mg} \mathrm{g}^{-1}\right)$ was calculated by the following equation [23]:

$Q=\frac{\left(C_{0}-C_{F}\right) \cdot V}{m}$

where $\mathrm{Q}\left(\mathrm{mg} \mathrm{g}^{-1}\right)$ is the mass of protein adsorbed by a unit amount of dry particles, $C_{0}\left(\mathrm{mg} \mathrm{mL}^{-1}\right)$ and $C_{F}\left(\mathrm{mg} \mathrm{mL}^{-1}\right)$ are the initial and final $\mathrm{BHb}$ solution concentration, $\mathrm{V}(\mathrm{mL})$ is the volume of the initial solution, $\mathrm{m}(\mathrm{g})$ is the mass of sorbent.

\subsubsection{Dynamic adsorption experiment}

In kinetic adsorption experiment, $5.0 \mathrm{mg}$ of M-MIPs, M-NIPs or $\mathrm{Fe}_{3} \mathrm{O}_{4} @ \mathrm{SiO}_{2}-\mathrm{GO}$ was suspended respectively in $5.0 \mathrm{~mL}$ of $0.3 \mathrm{mg} \mathrm{mL}^{-1} \mathrm{BHb}$ solution ( $\mathrm{pH}=8.0,10 \mathrm{mM} \mathrm{PBS}$ ). The suspensions were shaken at room temperature for different time intervals of 5-60 min. After that, the adsorbents were separated by an external magnet. The residual $\mathrm{BHb}$ concentration in the supernatant solution was determined with UV-vis spectrophotometry at $406 \mathrm{~nm}$.

\subsubsection{Selectivity and competitive adsorption experiment}

In order to estimate the selectivity of the magnetic molecularly imprinted polymers toward BHb, BSA, HSA and Lyz were selected as the competitive molecules due to their similar structure with the template. $10 \mathrm{mg}$ of the M-MIPs or M-NIPs was dispersed in $5.0 \mathrm{~mL}$ of $0.3 \mathrm{mg} \mathrm{L}^{-1} \mathrm{BHb}, \mathrm{BSA}$, Lyz, and HSA solution at room temperature for $4 \mathrm{~h}$. Then the sorbent was separated by an external magnet and the concentration of protein in the supernatant solution was determined with UV-vis spectrophotometry.

In competitive adsorption experiment of M-MIPs, $5 \mathrm{~mL}$ of a mixed solution of $\mathrm{BHb}$ and competitor protein was added into a centrifuge tube containing $10.0 \mathrm{mg}$ of M-MIPs under shaken at room temperature for $2 \mathrm{~h}$. Then the sorbent was separated by an external magnet and the proteins concentration was detected through a UV detector at $406 \mathrm{~nm}$ (BHb), $278 \mathrm{~nm}$ (BSA), $281 \mathrm{~nm}$ (HSA), and $290 \mathrm{~nm}$ (Lyz).

\subsubsection{Rebinding adsorption experiment}

Several groups of $10.0 \mathrm{mg}$ of M-MIPs or M-NIPs were added to $5.0 \mathrm{~mL}$ of $0.3 \mathrm{mg} \mathrm{mL}^{-1} \mathrm{BHb}$ solution $(\mathrm{pH}=8.0,10 \mathrm{mM}$ PBS). After incubating at room temperature for $2 \mathrm{~h}$, the M-MIPs or the M-NIPs were isolated using an external magnetic field. The residual $\mathrm{BHb}$ concentration in the supernatant solution was determined with UV-vis spectrophotometry at $406 \mathrm{~nm}$.

\subsection{Real sample analysis}

Firstly, the serum was diluted 100 times with phosphate buffer solution containing $1.0 \mathrm{mmol} \mathrm{L}^{-1} \mathrm{NaCl}$ (10.0 $\mathrm{mmol} \mathrm{L}^{-1}, \mathrm{pH} 6.0$ ) at room temperature. Then, $20.0 \mathrm{mg}$ of M-MIPs was mixed with $10.0 \mathrm{~mL}$ of serum samples for $45 \mathrm{~min}$. After that, the M-MIPs was firstly washed with $5.0 \mathrm{~mL}$ of $\mathrm{NaCl}$ solution $\left(5 \mathrm{mmol} \mathrm{L}^{-1}, \mathrm{pH} 7.0\right)$, and then eluted with $3.0 \mathrm{~mL}$ of $\mathrm{NaCl}$ solution $\left(0.25 \mathrm{~mol} \mathrm{~L}^{-1}\right.$, 
$\mathrm{pH}$ 7.0) for 40 min. Finally, diluted bovine blood samples, adsorbed bovine blood samples and eluent were analyzed with HPLC.

\section{Results and discussion}

\subsection{Synthesis of magnetic M-MIPs}

The preparation procedure for the M-MIPs was shown in Fig. 1. In our case, the amine functionalized magnetic mesoporous silica $\left(\mathrm{Fe}_{3} \mathrm{O}_{4} @ \mathrm{SiO}_{2}-\mathrm{NH}_{2}\right)$ was prepared in a reversed microemulsion system [27]. Simply, TEOS was added into the microemulsion to coat the $\mathrm{Fe}_{3} \mathrm{O}_{4}$ particle with silica layer, followed by addition of APTES for modification amino group onto the silica-coated magnetic nanoparticles surface. And then, NHS and EDC as the catalysts, $\mathrm{Fe}_{3} \mathrm{O}_{4} @ \mathrm{SiO}_{2}-\mathrm{NH}_{2}$ attached the surface of $\mathrm{GO}$ by amide bonds, $\mathrm{Si}-\mathrm{O}$ and $\mathrm{Fe}-\mathrm{O}$ bonds [5]. Thus, the $\mathrm{Fe}_{3} \mathrm{O}_{4} @ \mathrm{SiO}_{2}-\mathrm{GO}$ surface deposited with rich amino group has a high specific surface area and good dispersibility in an aqueous solution. Finally, the M-MIPs were prepared by self-polymerization of dopamine in alkaline aqueous solution.

In general, the molar ratio of functional monomer to template has an important influence on the specific affinity of M-MIPs. A series of M-MIPs were prepared with different amounts of $\mathrm{Fe}_{3} \mathrm{O}_{4} @ \mathrm{SiO}_{2}-\mathrm{GO}$, dopamine, and $\mathrm{BHb}$ and polymerization time. The adsorption performances of the M-MIPs were shown in Table 1, which indicated that the



Fig. 1 Synthesis of M-MIPs

Table 1 Preparation optimization of M-MIPs

\begin{tabular}{llllllll}
\hline Polymers & $\begin{array}{l}\text { Fe3O4@ } \\
\text { SiO2-GO } \\
(\mathrm{mg})\end{array}$ & $\begin{array}{lllll}\text { BHb } \\
(\mathrm{mg})\end{array}$ & $\begin{array}{c}\mathrm{DA} \\
(\mathrm{mg})\end{array}$ & $\begin{array}{l}\text { Stirring time } \\
(\mathrm{h})\end{array}$ & $\begin{array}{l}\text { Q of M-MIPs } \\
\left(\mathrm{mg} \mathrm{g}^{-1}\right)\end{array}$ & $\begin{array}{l}\text { Q of M-NIPs } \\
\left(\mathrm{mg} \mathrm{g}^{-1}\right)\end{array}$ & $\begin{array}{l}\text { Imprinted } \\
\text { factor }\end{array}$ \\
\hline M-MIPs1 & 300 & 80 & 200 & 4 & 56.03 & 45.55 & 1.23 \\
M-MIPs2 & 300 & 80 & 200 & 6 & 41.27 & 41.69 & 0.99 \\
M-MIPs3 & 300 & 80 & 200 & 7.5 & 63.16 & 34.90 & 1.81 \\
M-MIPs4 & 300 & 80 & 200 & 8 & 57.18 & 40.55 & 1.41 \\
M-MIPs5 & 300 & 80 & 160 & 7.5 & 46.79 & 32.05 & 1.46 \\
M-MIPs6 & 300 & 80 & 240 & 7.5 & 64.91 & 36.89 & 1.76 \\
M-MIPs7 & 300 & 80 & 200 & 7.5 & 78.09 & 77.32 & 1.01 \\
M-MIPs8 & 250 & 80 & 200 & 7.5 & 92.86 & 44.43 & 2.09 \\
M-MIPs9 & 200 & 80 & 200 & 7.5 & 52.68 & 27.30 & 1.93 \\
\hline
\end{tabular}


adsorption capacity of M-MIPs toward $\mathrm{BHb}$ reached the maximum when the amount of the $\mathrm{Fe}_{3} \mathrm{O}_{4} @ \mathrm{SiO}_{2}-\mathrm{GO}$ was $250 \mathrm{mg}$, and mass ratio of DA and $\mathrm{BHb}$ was $20: 8$, and the polymerization time was $7.5 \mathrm{~h}$.

\subsection{Characterization}

\subsubsection{Morphological characterization}

The morphological characterization of the prepared magnetic particles and composites were investigated by SEM and TEM. As depicted in Fig. $2 \mathrm{a}$, the $\mathrm{Fe}_{3} \mathrm{O}_{4} @ \mathrm{SiO}_{2}-\mathrm{NH}_{2}$ was found to be spherical. Figure $2 \mathrm{~b}$ shows that the $\mathrm{Fe}_{3} \mathrm{O}_{4} @$ $\mathrm{SiO}_{2}-\mathrm{NH}_{2}$ sphericals were assembled onto the surface of GO. As shown in Fig. 2c, after the imprinted layer based on the $\mathrm{Fe}_{3} \mathrm{O}_{4} @ \mathrm{SiO}_{2}-\mathrm{GO}$ was completed, the diameter of M-MIPs was larger than that of $\mathrm{Fe}_{3} \mathrm{O}_{4} @ \mathrm{SiO}_{2}-\mathrm{GO}$, which indicated the M-MIPs was prepared successfully.

TEM images of $\mathrm{Fe}_{3} \mathrm{O}_{4} @ \mathrm{SiO}_{2}-\mathrm{NH}_{2}, \mathrm{Fe}_{3} \mathrm{O}_{4} @ \mathrm{SiO}_{2}-\mathrm{GO}$ and M-MIPs were shown in Fig. $2 a_{1}-c_{1}$. Figure $2 a_{1}$ shows the presence of thick silica shell around $\mathrm{Fe}_{3} \mathrm{O}_{4}$ nanoparticles, which indicated that $\mathrm{Fe}_{3} \mathrm{O}_{4}$ nanoparticles have been coated by the silica layer successfully. Figure $2 b_{1}$ confirmed that $\mathrm{Fe}_{3} \mathrm{O}_{4} @ \mathrm{SiO}_{2}-\mathrm{NH}_{2}$ was completely grafted with $\mathrm{GO}$.
Compared with Fig. $2 b_{1}$, Fig. $2 c_{1}$ indicated the imprinted layer was coated on the surface of $\mathrm{Fe}_{3} \mathrm{O}_{4} @ \mathrm{SiO}_{2}-\mathrm{GO}$, making the surface of M-MIPs rough.

\subsubsection{FT-IR spectra analysis}

FT-IR spectroscopy was used to analyze the chemical structure of $\mathrm{Fe}_{3} \mathrm{O}_{4} @ \mathrm{SiO}_{2}-\mathrm{NH}_{2}, \mathrm{Fe}_{3} \mathrm{O}_{4} @ \mathrm{SiO}_{2}-\mathrm{GO}, \mathrm{M}$-MIPs before elution, M-NIPs and M-MIPs and the results were shown in Fig. 3. Absorption peak at $580 \mathrm{~cm}^{-1}$ existed in the all materials was attributed to the vibrational absorption peak of $\mathrm{Fe}-\mathrm{O}$ [28]. There are absorption peaks at $1103 \mathrm{~cm}^{-1}$ and $467 \mathrm{~cm}^{-1}$ in $\mathrm{Fe}_{3} \mathrm{O}_{4} @ \mathrm{SiO}_{2}-\mathrm{NH}_{2}$ (spectrum a) and $\mathrm{Fe}_{3} \mathrm{O}_{4} @$ $\mathrm{SiO}_{2}-\mathrm{GO}$ (spectrum b) corresponding to $\mathrm{Si}-\mathrm{O}-\mathrm{Si}$ and $\mathrm{Si}-\mathrm{O}$ tensile and deformation vibrations, respectively, which indicated the successful coating of $\mathrm{SiO}_{2}$ on $\mathrm{Fe}_{3} \mathrm{O}_{4}$ nanoparticles surface $[13,27]$. Compared with spectrum a and $\mathrm{b}$, the new absorption peaks at $2800 \mathrm{~cm}^{-1}$ and $3045 \mathrm{~cm}^{-1}$ existed in spectrum c corresponded to the stretching vibration of methylene groups, which confirmed that the amino-functionalization of the silica shell was successful [27]. Upon completion of the imprinting process, a typical phenyl absorption peak at $1630 \mathrm{~cm}^{-1}$ appeared at FT-IR spectrum of M-MIPs. The absorption peaks at $2848 \mathrm{~cm}^{-1}$
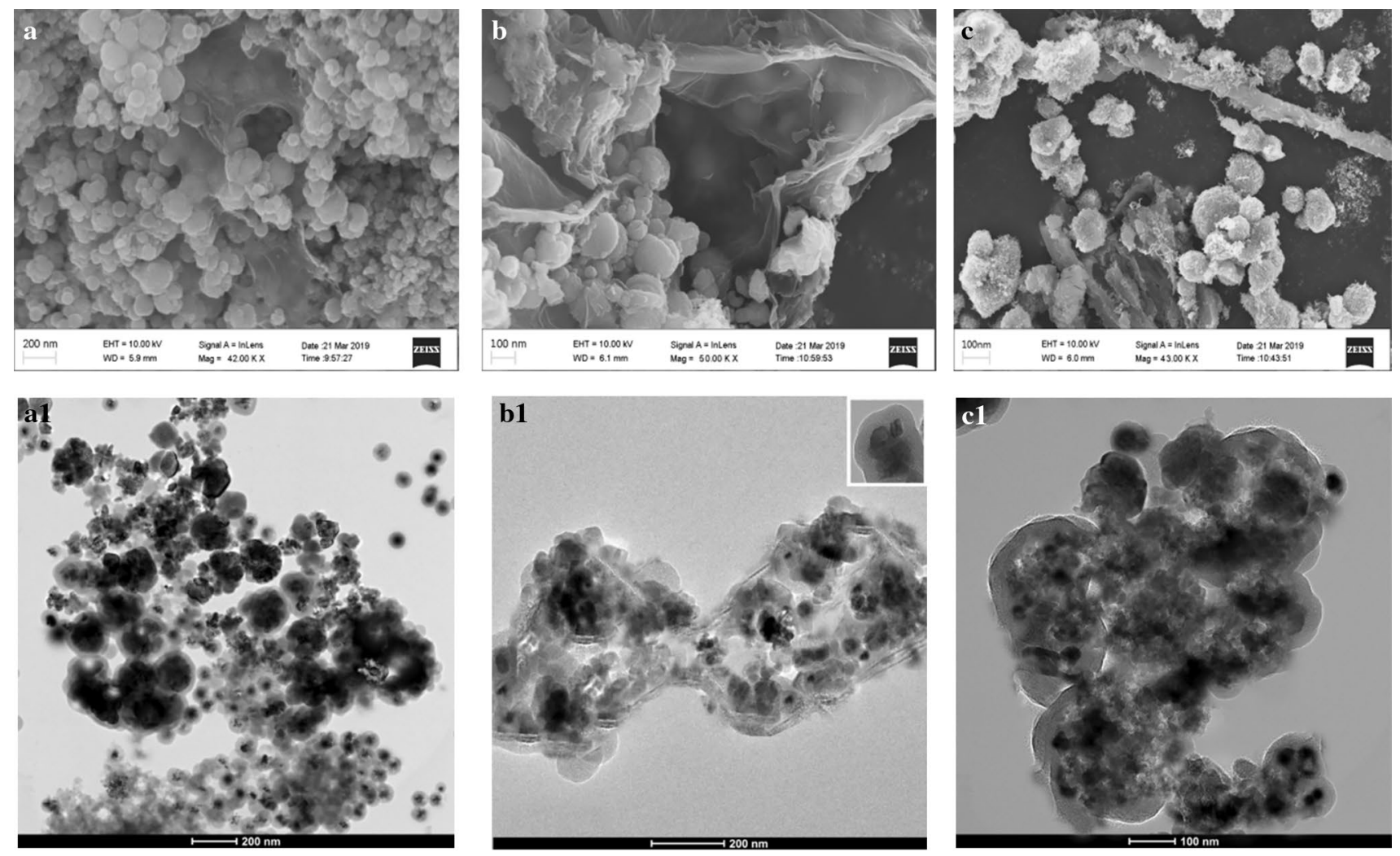

Fig. 2 SEM images of $\mathrm{Fe}_{3} \mathrm{O}_{4} @ \mathrm{SiO}_{2}-\mathrm{NH}_{2}(\mathbf{a}), \mathrm{Fe}_{3} \mathrm{O}_{4} @ \mathrm{SiO}_{2}-\mathrm{GO}(\mathbf{b})$, and M-MIPs (c) $;$ TEM images of $\mathrm{Fe}_{3} \mathrm{O}_{4} @ \mathrm{SiO}_{2}-\mathrm{NH}_{2}\left(\mathbf{a}_{\mathbf{1}}\right), \mathrm{Fe}_{3} \mathrm{O}_{4} @ S i O_{2}-\mathrm{GO}_{\left(\mathbf{b}_{1}\right)}$, and $\operatorname{M-MIPs}\left(\mathbf{c}_{1}\right)$ 


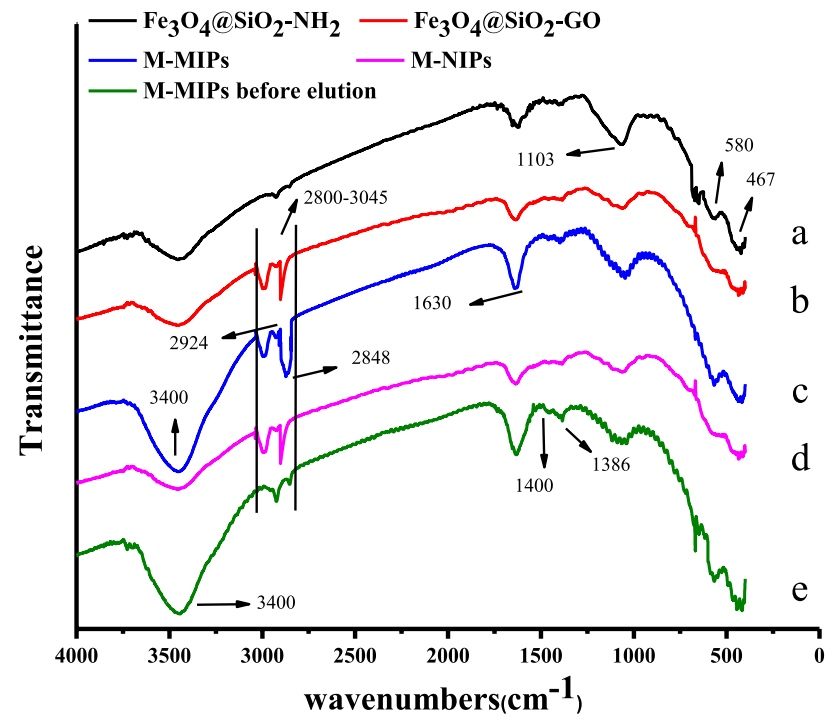

Fig. 3 Fourier transform infrared spectra of $\mathrm{Fe}_{3} \mathrm{O}_{4} @ \mathrm{SiO}_{2}-\mathrm{NH}_{2}$ (a), $\mathrm{Fe}_{3} \mathrm{O}_{4} @ \mathrm{SiO}_{2}-\mathrm{GO}$ (b), M-MIPs before elution (c), M-NIPs (d), and M-MIPs (e)

and $3400 \mathrm{~cm}^{-1}$ were greatly enhanced compared with spectrum c, which was derived from the stretching vibration of phenolic hydroxyl groups and amino groups [23]. The infrared spectrum of M-NIPs (spectrum d) was similar with the spectrum of M-MIPs (spectrum e). The absorption peak of $2924 \mathrm{~cm}^{-1}$ was produced by $-\mathrm{OH}$ stretching vibration, which was not found in the spectrum of M-MIPs before elution (spectrum e). These results indicated that dopamine and $\mathrm{BHb}$ were successfully polymerized on the surface of the $\mathrm{Fe}_{3} \mathrm{O}_{4} @ \mathrm{SiO}_{2}-\mathrm{GOs}$.

\subsubsection{Magnetic performance}

The magnetic hysteresis loops of the synthesized magnetic adsorbents were shown in Fig. S1 in supplementary material. Magnetic characterization results showed that the magnetic saturation values for $\mathrm{Fe}_{3} \mathrm{O}_{4}$ nanoparticles, $\mathrm{Fe}_{3} \mathrm{O}_{4} @ \mathrm{SiO}_{2}-\mathrm{NH}_{2}, \mathrm{Fe}_{3} \mathrm{O}_{4} @ \mathrm{SiO}_{2}-\mathrm{GO}$ and M-MIPs were 64, 54,34 , and $21 \mathrm{emu} \mathrm{g}^{-1}$, respectively. The lower saturation magnetism of the M-MIPs compared with the $\mathrm{Fe}_{3} \mathrm{O}_{4} @ \mathrm{SiO}_{2}$ $\mathrm{GO}$ was ascribed to the shielding effect of the imprinted layer on the M-MIPs. Nevertheless, the M-MIPs composite can be easily isolated from the sample solution with the help of an external magnet. As shown in Fig. S1e, the M-MIPs were quickly separated from the aqueous solution (10 s) with an external magnet.

\subsection{Adsorption experiment}

\subsubsection{Isothermal adsorption analysis}

The adsorption isotherms of the M-MIPs, M-NIPs and $\mathrm{Fe}_{3} \mathrm{O}_{4} @ \mathrm{SiO}_{2}-\mathrm{GO}$ toward $\mathrm{BHb}$ were examined via batch rebinding tests at different initial $\mathrm{BHb}$ concentrations ranged from 0.05 to $0.45 \mathrm{mg} \mathrm{mL}^{-1}$. The saturated adsorption capacity was fitted respectively with the Freundlich adsorption model and Langmuir adsorption model. The Freundlich adsorption model is an empirical model that assumes the adsorption is on a heterogeneous surface. The equation is as follows [13]:

$Q_{e q}=K_{f} C_{e}^{1 / n}$

A linear equation was obtained by taking the logarithm of Freundlich equation [29]

$\lg Q_{e}=\frac{1}{n} \lg C_{e}+\lg K_{f}$

where $C_{e}\left(\mathrm{mg} \mathrm{mL}^{-1}\right)$ and $\mathrm{Q}_{\mathrm{eq}}\left(\mathrm{mg} \mathrm{g}^{-1}\right)$ are the concentration of $\mathrm{BHb}$ and adsorbed amount in the equilibrium state, respectively. $K_{f}\left(\mu \mathrm{mol} \mathrm{g}^{-1}\right)$ is the Freundlich coefficient, which is an index of the adsorption capacity of the adsorbent.

The Langmuir equation is follows [23]:

$Q_{e q}=\frac{Q_{\max } C_{e}}{1 / K_{L}+C_{e}}$

where $\mathrm{Q}_{\mathrm{eq}}\left(\mathrm{mg} \mathrm{g}^{-1}\right)$ and $\mathrm{Q}_{\max }\left(\mathrm{mg} \mathrm{g}^{-1}\right)$ are the experimental and theoretical maximum adsorption capacity of the adsorbent toward the protein, respectively. $\mathrm{K}_{\mathrm{L}}\left(\mathrm{mg} \mathrm{mL}^{-1}\right)$ is the dissociation constant of Langmuir equation. The results were shown in Fig. S2 and the relative parameters calculated from these isotherms were listed in Table 2. As shown in Fig. S2 in supplementary material, compared to
Table 2 Isotherm parameters for the adsorption of $\mathrm{BHb}$ by M-MIPs, M-NIPs, and $\mathrm{Fe}_{3} \mathrm{O}_{4} @$ $\mathrm{SiO}_{2}-\mathrm{GO}$

\begin{tabular}{|c|c|c|c|c|c|c|}
\hline & \multicolumn{3}{|c|}{ Langmuir adsorption model } & \multicolumn{3}{|c|}{ Freundlich adsorption model } \\
\hline & $\begin{array}{l}\mathrm{Q}_{\max } \\
\left(\mathrm{mg} \mathrm{g}^{-1}\right)\end{array}$ & $\mathrm{R}^{2}$ & $\begin{array}{l}\mathrm{K}_{\mathrm{L}} \\
\left(\mathrm{L} \mathrm{mg}^{-1}\right)\end{array}$ & $\begin{array}{l}\mathrm{K}_{\mathrm{f}} \\
\left(\mu \mathrm{mol} \mathrm{g}{ }^{-1}\right)\end{array}$ & $\mathrm{R}^{2}$ & $\mathrm{n}$ \\
\hline M-MIPs & 164.47 & 0.916 & 4.58 & 0.86 & 0.890 & 1.16 \\
\hline M-NIPs & 88.79 & 0.817 & 7.33 & 0.87 & 0.902 & 1.31 \\
\hline $\mathrm{Fe}_{3} \mathrm{O}_{4} @ \mathrm{SiO}_{2}-\mathrm{GO}$ & 90.25 & 0.813 & 5.63 & 0.24 & 0.904 & 1.04 \\
\hline
\end{tabular}


with the M-NIPs, the M-MIPs had higher adsorption capacity. Moreover, the adsorption capacity of the M-MIPs in this paper were better than that of the previous studies [23, 24], which demonstrated the excellent adsorption capacity of the M-MIPs toward BHb. In addition, the correlation coefficients $\left(R^{2}\right)$ of the Langmuir adsorption isotherm were higher than that of the Freundlich adsorption isotherm. The $Q_{\max }$ and $K_{L}$ values of Langmuir equation were estimated to be $164.4 \mathrm{mg} \mathrm{g}^{-1}$ and $4.6 \mathrm{~L} \mathrm{mg}^{-1}$ for the M-MIPs. The $K_{L}$ of the imprinted particles expressed much lower than that of the non-imprinted, which indicated that the binding sites of the M-MIPs are uniformly dispersed on the surface, and the adsorption mechanism is a controlled single-layer adsorption.

\subsubsection{Adsorption kinetics analysis}

The adsorption kinetics of M-MIPs, M-NIPs, and $\mathrm{Fe}_{3} \mathrm{O}_{4} @$ $\mathrm{SiO}_{2}-\mathrm{GO}$ toward $\mathrm{BHb}$ were investigated and the results were shown in Fig. S3 in supplementary material. The adsorption of the M-MIPs toward $\mathrm{BHb}$ reached the equilibrium at 40 min, and the adsorption of $\mathrm{M}-\mathrm{NIPs}$ and $\mathrm{Fe}_{3} \mathrm{O}_{4} @$ $\mathrm{SiO}_{2}-\mathrm{GO}$ toward $\mathrm{BHb}$ reached the equilibrium at $35 \mathrm{~min}$. The maximum adsorption capacity of the M-MIPs was higher than that of the M-NIPs and $\mathrm{Fe}_{3} \mathrm{O}_{4} @ \mathrm{SiO}_{2}-\mathrm{GO}$, which is due to the introduction of a large number of imprinted recognition sites in the M-MIPs during the preparation process. Compared with the previous work [23], the M-MIPs prepared in this experiment had a shorter time to reach adsorption equilibrium.

In order to study the rate control and mass transfer mechanism of the adsorption process, the pseudo-firstorder and pseudo-second-order model was used to fit the experimental data [30].

$\ln \left(Q_{e}-Q_{t}\right)=\ln Q_{e}-k_{1} t \quad$ (pseudo - first - order model)

$\frac{t}{Q_{t}}=\frac{1}{k_{2} Q_{e}^{2}}+\frac{t}{Q_{e}}$ (pseudo - second - order model $)$

where $Q_{e}\left(\mathrm{mg} \mathrm{g}^{-1}\right)$ and $Q_{t}\left(\mathrm{mg} \mathrm{g}^{-1}\right)$ are the equilibrium adsorption capacity and adsorption capacity at a real time, respectively. $\mathrm{k}_{1}\left(\mathrm{~s}^{-1}\right)$ is the adsorption rate constant of pseudo-first-order adsorption; and $\mathrm{k}_{2}\left(\mathrm{mg} \mathrm{g}^{-1} \mathrm{~s}^{-1}\right)$ is the adsorption rate constant of pseudo-second-order adsorption. The relative parameters of the pseudo-first-order adsorption model and the pseudo-second-order adsorption model for the M-MIPs, M-NIPs, and $\mathrm{Fe}_{3} \mathrm{O}_{4} @ \mathrm{SiO}_{2}-\mathrm{GO}$ toward $\mathrm{BHb}$ were listed in Table 3. The results showed the proposed pseudo-second-order model was suitable for explanation for the adsorption process of the M-MIPs toward BHb.

\subsubsection{Selectivity of M-MIPs}

The selectivity test of the M-MIPs and M-NIPs was carried out by using BSA, HSA, Lyz as the comparative proteins because they have a broad isoelectric point ( $\mathrm{pl}$ ). As shown in Fig. 4, the binding capacity of M-MIPs toward $\mathrm{BHb}$ was much higher than that of the competitive protein, which was attributed to the binding sites of M-MIPs are complementary to $\mathrm{BHb}$. The recognition property of the M-MIPs toward BHb was evaluated by the imprinting factor (a) which is defined as follow [31]:

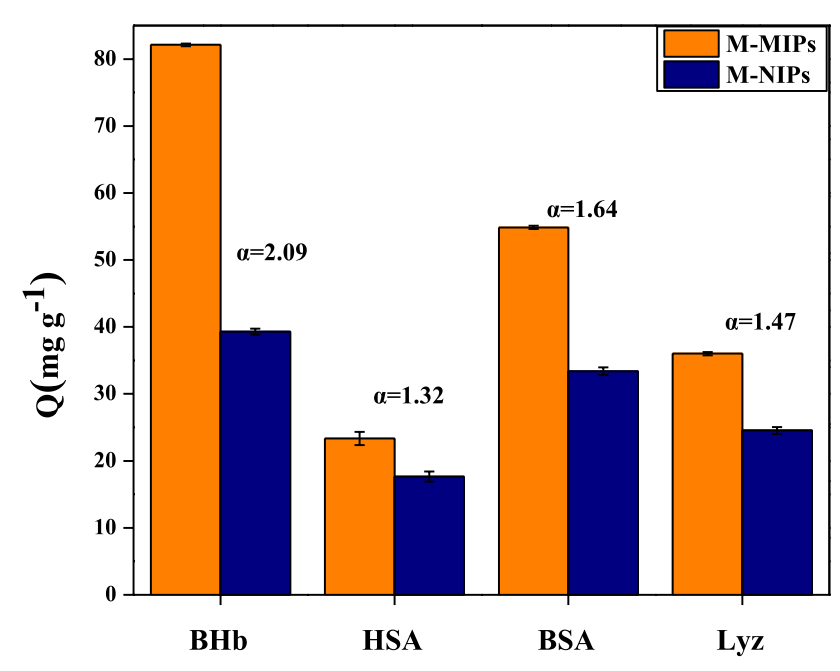

Fig. 4 Selective adsorption of the M-MIPs and M-NIPs toward BHb, HSA, BSA and Lyz
Table 3 Kinetic parameters for the adsorption of $\mathrm{BHb}$ by M-MIPs, M-NIPs, and $\mathrm{Fe}_{3} \mathrm{O}_{4} @$ $\mathrm{SiO}_{2}-\mathrm{GO}$

\begin{tabular}{|c|c|c|c|c|c|c|}
\hline \multirow[t]{2}{*}{ Polymers } & \multicolumn{3}{|c|}{ Pseudo-first-order kinetics } & \multicolumn{3}{|c|}{ Pseudo-second-order kinetics } \\
\hline & $\mathrm{R}^{2}$ & $\begin{array}{l}\text { Qe } \\
\left(\mathrm{mg} \mathrm{g}^{-1}\right)\end{array}$ & $\begin{array}{l}\mathrm{K}_{1} \\
\left(\min ^{-1}\right)\end{array}$ & $\overline{\mathrm{R}^{2}}$ & $\begin{array}{l}\mathrm{Qe} \\
\left(\mathrm{mg} \mathrm{g}^{-1}\right)\end{array}$ & $\begin{array}{l}\mathrm{K}_{2} \\
\left(\min ^{-1}\right)\end{array}$ \\
\hline M-MIPs & 0.986 & 82.572 & 0.04 & 0.989 & 105.104 & 0.037 \\
\hline M-NIPs & 0.988 & 56.988 & 0.065 & 0.993 & 66.445 & 0.075 \\
\hline $\mathrm{Fe}_{3} \mathrm{O}_{4} @ \mathrm{SiO}_{2}-\mathrm{GO}$ & 0.984 & 47.575 & 0.078 & 0.989 & 52.743 & 0.109 \\
\hline
\end{tabular}


$\alpha=\frac{Q_{M-M I P s}}{Q_{M-N I P s}}$

where $\mathrm{Q}_{\mathrm{M} \text {-MIPs }}$ and $\mathrm{Q}_{\mathrm{M} \text {-NIPs }}$ are the adsorption capacities of the M-MIPs and M-NIPs, respectively. The imprinting factors (a) were calculated to be $2.09,1.32,1.64$, and 1.47 for $\mathrm{BHb}, \mathrm{HSA}, \mathrm{BSA}$, and Lyz, respectively, which indicated that the imprinted sites complementary with the template $\mathrm{BHb}$ in shape, size and functionality were formed in the process of imprinting. The selectivity of the M-MIPs was evaluated by the selective factor $(\beta)$ which is defined as follows [32]:

$\beta=\frac{\alpha_{1}}{\alpha_{2}}$

where $a_{1}$ is the imprinting factors of $B H b, a_{2}$ is the other competitive proteins. The selectivity factors $(\beta)$ for BSA, HSA, and Lyz were 1.27, 1.58 and 1.42, respectively, demonstrating the M-MIPs owned the higher selectivity for $\mathrm{BHb}$.

The concentration of $\mathrm{BHb}$ was fixed in the mixed protein solution $\left(0.3 \mathrm{mg} \mathrm{mL}^{-1}\right)$, and the concentrations of the competitive protein were ranged from 0.1 to $0.5 \mathrm{mg} \mathrm{mL}^{-1}$. As shown in Table 4, compared with single protein, the adsorption capacity of M-MIPs and M-NIPs decreased about 8-16 $\mathrm{mg} \mathrm{g}^{-1}$, which indicated that the concentration of competitive protein had a little influence on the adsorption performance of M-MIPs

In order to further verify the specificity of M-MIPs, the mixed system of four proteins was prepared with the fixed concentration of $\mathrm{BHb}\left(0.3 \mathrm{mg} \mathrm{mL}^{-1}\right)$ and the different

Table 4 Adsorption capacity of M-MIPs and M-NIPs toward BHb in two mixed protein solution

\begin{tabular}{|c|c|c|c|}
\hline \multirow{2}{*}{\multicolumn{2}{|c|}{$\begin{array}{l}\text { Concentration ratio of } \mathrm{BHb} \text { and com- } \\
\text { petitive protein }\left(\mathrm{mg} \mathrm{mL}^{-1}\right)\end{array}$}} & \multicolumn{2}{|c|}{$\mathrm{Q}\left(\mathrm{mg} \mathrm{g}^{-1}\right)$} \\
\hline & & \multirow{2}{*}{$\frac{\text { M-MIPs }}{78.91}$} & \multirow{2}{*}{$\frac{\text { M-NIPs }}{38.68}$} \\
\hline BHb:BSA & $0.3: 0.1$ & & \\
\hline & $0.3: 0.2$ & 78.61 & 38.16 \\
\hline & $0.3: 0.3$ & 77.41 & 37.61 \\
\hline & $0.3: 0.4$ & 76.67 & 36.72 \\
\hline & $0.3: 0.5$ & 76.03 & 36.65 \\
\hline \multirow[t]{5}{*}{ BHb:HSA } & $0.3: 0.1$ & 79.97 & 38.55 \\
\hline & $0.3: 0.2$ & 78.90 & 38.34 \\
\hline & $0.3: 0.3$ & 78.31 & 37.75 \\
\hline & $0.3: 0.4$ & 77.92 & 37.51 \\
\hline & $0.3: 0.5$ & 77.18 & 37.81 \\
\hline \multirow[t]{5}{*}{ BHb:Lyz } & $0.3: 0.1$ & 83.99 & 40.15 \\
\hline & $0.3: 0.2$ & 83.90 & 40.33 \\
\hline & $0.3: 0.3$ & 82.18 & 39.71 \\
\hline & $0.3: 0.4$ & 80.62 & 39.12 \\
\hline & $0.3: 0.5$ & 80.03 & 39.55 \\
\hline
\end{tabular}

concentration of competitive proteins $\left(0.1 \mathrm{mg} \mathrm{mL}^{-1}\right.$, $0.2 \mathrm{mg} \mathrm{mL}^{-1}$ and $0.3 \mathrm{mg} \mathrm{mL}^{-1}$ ). As shown in Table 5, the adsorption capacity of M-MIPs and M-NIPs toward BHb reduced about $9 \mathrm{mg} \mathrm{g}^{-1}$, which indicated that the rise of competitive protein concentration in the solution causes the binding site to be occupied. However, the adsorption capacity of M-MIPs to BHb keep at high level $\left(\mathrm{Q}=79.9 \mathrm{mg} \mathrm{g}^{-1}\right)$.

\subsubsection{Reproducibility of M-MIPs}

The reusability and reproducibility are the important properties for the application of imprinted polymers. The results of cycles adsorption and elution processes by using the same batch of M-MIPs were shown in Fig. S4. After twelve adsorption-desorption cycles, the adsorption capacity of M-MIPs toward BHb decreased about 14.1\%, which may be as a consequence of the damage of some imprinted cavities for $\mathrm{BHb}$ in the repeated elution process [2]. The data confirmed the M-MIPs possess a high stability and excellent reusability performance.

\subsection{Optimization of imprinted solid phase extraction condition}

In order to obtain excellent extraction efficiency, several extraction conditions including washing solvent, $\mathrm{pH}$ of the eluent and desorption time were studied in detail. Firstly, $10.0 \mathrm{mg}$ of the M-MIPs was immersed into $5.0 \mathrm{~mL}$ of $0.5 \mathrm{mg} \mathrm{mL}^{-1} \mathrm{BHb}$ for $2 \mathrm{~h}$. When one of the parameters was changed, the other parameters were fixed to their optimized values.

Table 5 Adsorption capacity of M-MIPs and M-NIPs to BHb in multiprotein mixed solution

\begin{tabular}{lllll}
\hline $\begin{array}{l}\text { Concentration ratio of } \\
\begin{array}{l}\text { BHb and other proteins } \\
\left(\mathrm{mg} \mathrm{mL}^{-1}\right)\end{array}\end{array}$ & \multicolumn{2}{l}{$\mathrm{Q}\left(\mathrm{mg} \mathrm{g}^{-1}\right)$} & IF \\
\cline { 3 - 4 } $0.3: 0.1$ & M-MIPs & M-NIPs & \\
\hline & BHb & 82.11 & 39.33 & 2.08 \\
& BSA & 39.93 & 24.90 & 1.60 \\
& HSA & 25.41 & 18.61 & 1.37 \\
$0.3: 0.2$ & Lyz & 27.67 & 19.22 & 1.43 \\
& BHb & 79.87 & 38.55 & 2.06 \\
& BSA & 37.79 & 23.05 & 1.64 \\
& HSA & 22.42 & 16.25 & 1.38 \\
$0.3: 0.3$ & Lyz & 25.92 & 18.51 & 1.40 \\
& BHb & 81.31 & 39.45 & 2.06 \\
& BSA & 39.18 & 24.18 & 1.62 \\
& HSA & 24.57 & 18.39 & 1.34 \\
& Lyz & 27.02 & 18.42 & 1.47 \\
\hline
\end{tabular}


Table 6 Effect of $\mathrm{pH}$ and temperature on $\mathrm{BHb}$ adsorption amounts by M-MIPs

\begin{tabular}{llllll}
\hline $\mathrm{pH}$ & 5 & 6 & 7 & 8 & 9 \\
\hline $\mathrm{Q}\left(\mathrm{mg} \mathrm{g}^{-1}\right)$ & 49.01 & 52.81 & 71.11 & 75.09 & 54.1 \\
Temperature $\left({ }^{\circ} \mathrm{C}\right)$ & 15 & 20 & 25 & 30 & 35 \\
$\mathrm{Q}\left(\mathrm{mg} \mathrm{g}^{-1}\right)$ & 48.01 & 56.81 & 69.11 & 71.09 & 51.1 \\
\hline
\end{tabular}

\subsubsection{Effect of temperature and $\mathrm{pH}$ to M-MIPs extraction performance}

Studies showed solution $\mathrm{pH}$ can affect the adsorption capacity of the M-MIPs toward protein [30]. In this study, $10 \mathrm{mg}$ of the M-MIPs was immersed into $\mathrm{BHb}$ solution with different $\mathrm{pH}$ values ranged from 3.0 to 9.0 at $30^{\circ} \mathrm{C}$ for $2 \mathrm{~h}$ to investigate the maximum adsorption capacity. As shown in Table 6, the M-MIPs showed the maximum adsorption capacity toward $\mathrm{BHb}$ at $\mathrm{pH} 8.0(\mathrm{RSD}<4.3 \%, \mathrm{n}=3)$.

The effects of adsorption temperature ranged from 15 to $35^{\circ} \mathrm{C}$ on the adsorption performance of $\mathrm{BHb}$ were investigated in detail under $\mathrm{pH}$ 8. As shown in Table 6, the maximum adsorption capacity of the M-MIPs toward $\mathrm{BHb}$ was achieved at $30^{\circ} \mathrm{C}$, and the adsorption capacity the M-MIPs toward $\mathrm{BHb}$ decreased rapidly when temperature decreased or increased.

\subsubsection{Effect of washing solvent and eluent solvent}

In order to reduce the impurity content, suitable washing solvent was selected in the magnetic solid phase extraction process. In this study, $5.0 \mathrm{~mL}$ of different types of washing solvents including $\mathrm{NaCl}$ solution $\left(10.0 \mathrm{mmol} \mathrm{L}^{-1}\right.$, $\mathrm{pH}$ 7.0), PBS (10.0 mmol L $\left.{ }^{-1}, \mathrm{pH} 7.0\right)$, methanol/HAc with different ratios (10:90, 50:50, 90:10) were tested. As shown in Fig. $5 \mathrm{a}$, when $5.0 \mathrm{~mL}$ of PBS $\left(10.0 \mathrm{mmol} \mathrm{L}^{-1}, \mathrm{pH} 7.0\right)$ was used as the washing solvent, the maximum recovery of $\mathrm{BHb}$ from the M-NIPs was obtained (65.0\%) due to the non-specific adsorption, while $8.4 \%$ of that was obtained from the M-MIPs. Therefore, $5.0 \mathrm{~mL}$ of PBS $(10.0 \mathrm{mmol} \mathrm{L}$, $\mathrm{pH}=7)$ was selected as the optimum washing solvent.

In this study, different types of eluents such as $\mathrm{NaCl}\left(0.25 \mathrm{~mol} \mathrm{~L}^{-1}, \mathrm{pH} 7.0\right), \mathrm{PBS} / \mathrm{NaCl}(50: 50, \mathrm{pH} 7), \mathrm{PBS}$ $\left(10.0 \mathrm{mmol} \mathrm{L}^{-1}, \mathrm{pH} 7.0\right), \mathrm{NaOH}\left(10.0 \mathrm{mmol} \mathrm{L}^{-1}\right), 2 \%$ SDS$\mathrm{HAc}(\mathrm{w} / \mathrm{v}, \mathrm{v} / \mathrm{v})$ were used to elute BHb from the M-MIPs. As shown in Fig. $5 \mathrm{~b}, \mathrm{NaCl}\left(0.25 \mathrm{~mol} \mathrm{~L}^{-1}, \mathrm{pH} 7.0\right)$ and $\mathrm{NaOH}$ $\left(10.0 \mathrm{mmol} \mathrm{L}^{-1}\right), 2 \%$ SDS-HAc (w/v) showed higher $\mathrm{BHb}$ recovery than that of other eluents. However, SDS-HAC and $\mathrm{NaOH}$ would destroy protein structure [33]. Thus, $\mathrm{NaCl}\left(0.25 \mathrm{~mol} \mathrm{~L}^{-1}, \mathrm{pH} 7.0\right)$ was used as the eluent in this experiment.

Additional, the effects of different volume of $\mathrm{NaCl}$ solution ( $2.5 \mathrm{~mL}, 3.5 \mathrm{~mL}, 4.5 \mathrm{~mL}, 5.5 \mathrm{~mL}$ ) on the recovery
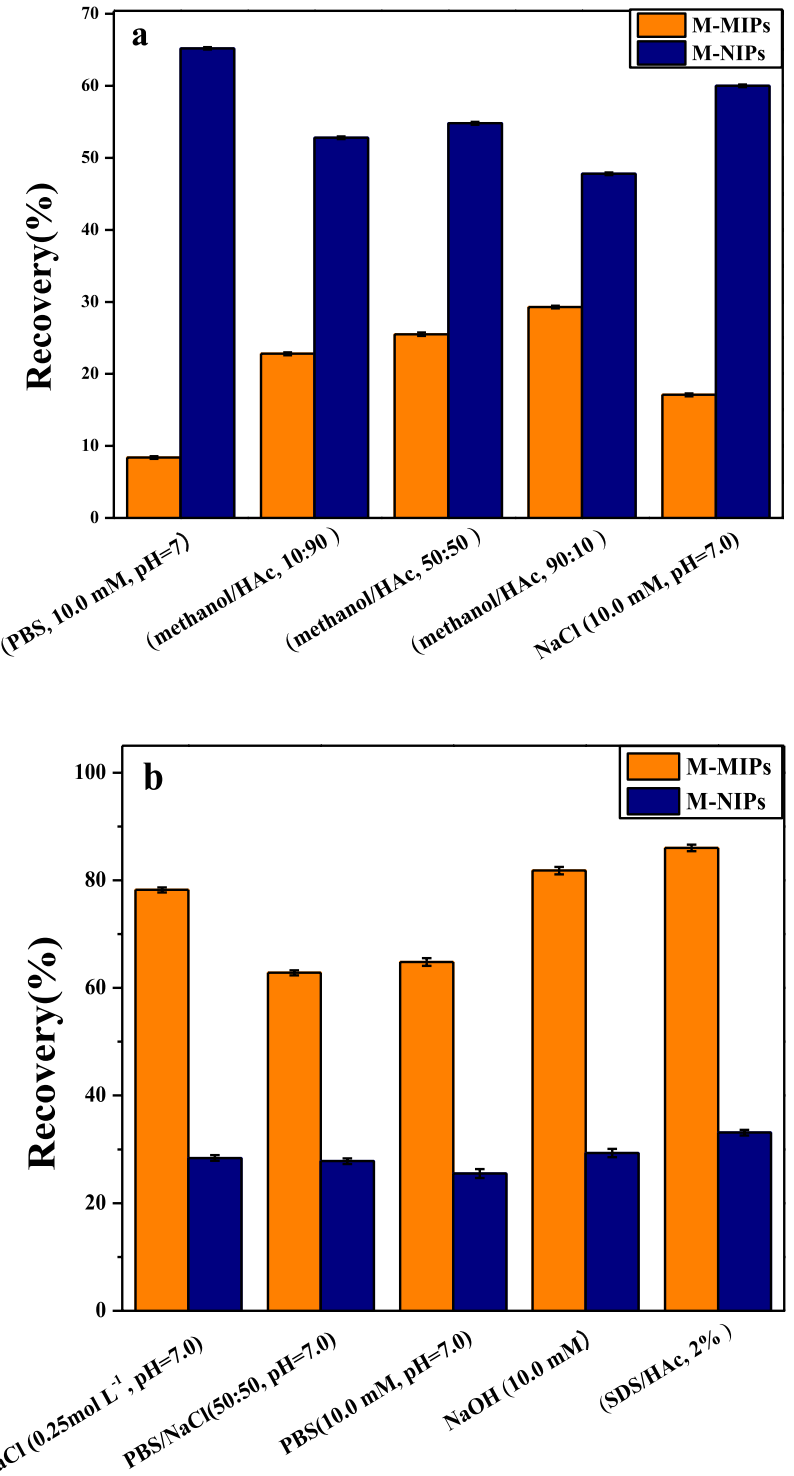

Fig. 5 Effects of washing solvent (a) and eluent (b) on the recovery of $\mathrm{BHb}$

of $\mathrm{BHb}$ were discussed. The results showed that the recovery rate increased with the increment of the volume of eluent when the volume of the eluent was less $4.5 \mathrm{~mL}$. The recovery of $\mathrm{BHb}$ remained stable when the volume exceeded $4.5 \mathrm{~mL}$. NaCl solutions with different $\mathrm{pH}$ values have different effects on the elution efficiency of the protein. The results showed the highest recovery (84.5\%) for $\mathrm{BHb}$ was obtained at $\mathrm{pH}=7$. Therefore, $4.5 \mathrm{~mL}$ of $\mathrm{NaCl}$ solution $\left(0.25 \mathrm{~mol} \mathrm{~L}^{-1}, \mathrm{pH} 7.0\right)$ was chosen as the optimum eluent in this study. 


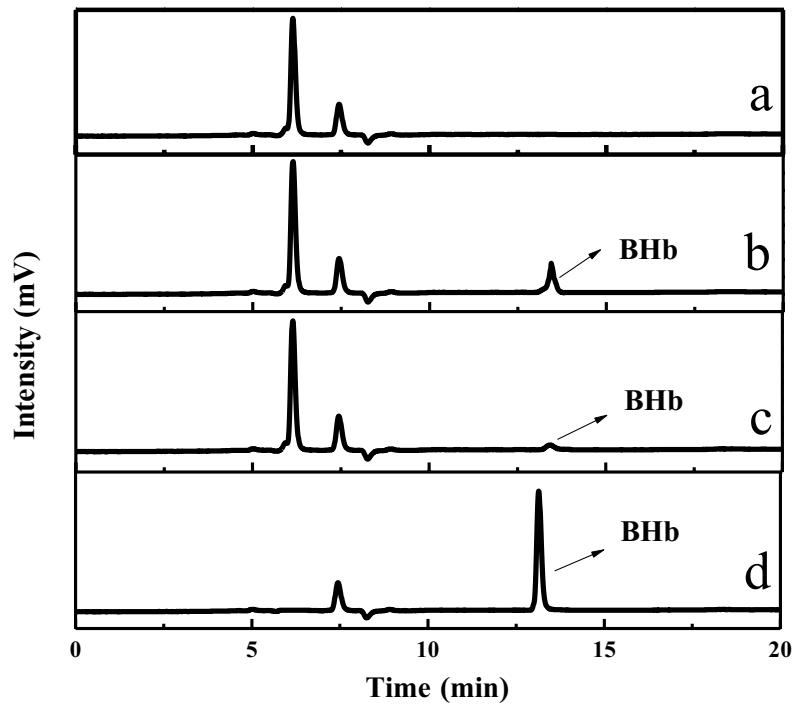

Fig. 6 The chromatograms of bovine calf serum sample (a), $\mathrm{BHb}$ spiked to bovine calf serum sample (b), after pretreatment by M-MIPs (c), and eluate (d)

Table 7 Analytical results for $\mathrm{BHb}$ in bovine calf serum samples $(\mathrm{n}=5)$

\begin{tabular}{llll}
\hline Sample & $\begin{array}{l}\text { Added } \\
\left(\mathrm{mg} \mathrm{mL}^{-1}\right)\end{array}$ & Found $\left(\mathrm{mg} \mathrm{mL}^{-1}\right)$ & Recovery (\%) \\
\hline 1 & Blank & $0.050 \pm 0.002$ & - \\
2 & 0.010 & $0.059 \pm 0.005$ & 90.71 \\
3 & 0.050 & $0.092 \pm 0.007$ & 84.61 \\
4 & 0.100 & $0.153 \pm 0.008$ & 102.56 \\
5 & 0.150 & $0.190 \pm 0.011$ & 93.63 \\
6 & 0.200 & $0.231 \pm 0.013$ & 90.74 \\
\hline
\end{tabular}

\subsubsection{Desorption time}

On the basis of the above optimized conditions, the desorption time was further optimized. As shown in Fig. S5, the recovery of $\mathrm{BHb}$ from the M-MIPs increased rapidly in the first $40 \mathrm{~min}$ and then remained stable at $85 \%$. Therefore, $40 \mathrm{~min}$ was selected as the appropriate desorption time.

\subsection{Application}

M-MIPs were used as adsorbents for M-SPE BHb in bovine serum under the above optimized solid phase extraction conditions to evaluate the separation and enrichment of $\mathrm{BHb}$ from real sample. The results were shown in Fig. 6. A small chromatographic peak of $\mathrm{BHb}$ was observed in Fig. 6a (calf serum sample). However, when $\mathrm{BHb}$ standard solution was added, $\mathrm{BHb}$ peak in the spiked serum chromatogram was clearly detected (Fig. 6b). Compared with Fig. $6 \mathrm{~b}$ and $\mathrm{c}, \mathrm{BHb}$ chromatographic peak in Fig. $6 \mathrm{~d}$ increased significantly. The above results indicated that M-MIPs exhibited excellent selective separation and enrichment performance for $\mathrm{BHb}$. By comparing the concentration of $\mathrm{BHb}$ in the spiked bovine serum and the eluate, the enrichment factor of M-MIPs toward BHb was calculated as 15, which indicated the M-MIPs possessed excellent enrichment ability toward $\mathrm{BHb}$.

The bovine calf serum analysis was carried out by spiked recovery method to investigate the separation and enrichment performance of the M-MIPs, and the results were represented in Table 7 . The recoveries of the spiked samples was ranged from 84.64 to $102.56 \%$, which indicated that the proposed method was suited for the specific separation and extraction of $\mathrm{BHb}$ in real sample. Moreover, the comparison of the parameter of proposed M-MIPs with the other method for separation $\mathrm{BHb}$ was shown in Table 8 [23, 29, 34-36]. The M-MIPs showed higher adsorption capacity and shorter adsorption equilibrium time.

\section{Conclusions}

Novel M-MIPs based on magnetic rich-amine mesoporous silica/graphene oxide were synthesized with surface imprinting technique. The amino coated $\mathrm{Fe}_{3} \mathrm{O}_{4}$ nanoparticles were introduced to graphene oxide surface by an inverse microemulsion method for facilitating surface polymerization dopamine imprinted layer. The protein adsorption on the imprinted surface was monolayer adsorption, and the adsorption kinetics conforms to a pseudo-second-order kinetic model. The recoveries of the
Table 8 Performance comparison of the M-MIPs and other reported molecularly imprinted polymers, different imprinting method

\begin{tabular}{lllllll}
\hline Carrier & Template & Capacity $\left(\mathrm{mg} \mathrm{g}^{-1}\right)$ & $\begin{array}{l}\text { Imprinting } \\
\text { factor }(\mathrm{a})\end{array}$ & $\begin{array}{l}\text { Adsorption } \\
\text { time }(\mathrm{min})\end{array}$ & Recovery (\%) & Reference \\
\hline MWCNTs@GO & $\mathrm{BSA}$ & 78.12 & 2.85 & 60 & $84.0-94.5$ & {$[23]$} \\
$\mathrm{Fe}_{3} \mathrm{O}_{4}$ & $\mathrm{BHb}$ & 124.86 & 1.99 & 125 & - & {$[29]$} \\
$\mathrm{Fe}_{3} \mathrm{O}_{4}$ & $\mathrm{BSA}$ & 71.85 & 1.7 & 120 & - & {$[34]$} \\
$\mathrm{Fe}_{3} \mathrm{O}_{4} @ \mathrm{SiO}_{2}$ & $\mathrm{BHb}$ & 4.65 & 1.51 & 60 & - & {$[35]$} \\
$\mathrm{Fe}_{3} \mathrm{O}_{4} @ \mathrm{SiO}_{2}$ & $\mathrm{BHb}$ & - & - & 70 & $97.49-100.62$ & {$[36]$} \\
$\mathrm{Fe}_{3} \mathrm{O}_{4} @ \mathrm{SiO}_{2}-\mathrm{GO}$ & $\mathrm{BHb}$ & 164.47 & 2.06 & 40 & $84.61-102.56$ & This work \\
\hline
\end{tabular}


bovine hemoglobin in spiked bovine calf serum samples were range of $84.6-102.5 \%$. The fascinating M-MIPs provided an alternative method for the separation of protein.

Acknowledgements This work is supported by the National Natural Science Foundation of China (No. 21767011 and 21565014); Hunan province graduate student scientific research innovation Project (CX2018B705); Hunan Province Manganese Zinc and Vanadium Industry Technology Collaborative Innovation Center Research and Innovation Project (2018mzvg006).

\section{Compliance with ethical standards}

Conflict of interest All the authors declare no conflict of interest.

\section{References}

1. Chen LX, Wang XY, Lu WH et al (2016) Molecular imprinting: perspectives and applications. Chem Soc Rev 45(8):2137-2211

2. Cao F, Wang L, Yao Y et al (2018) Synthesis and application of a highly selective molecularly imprinted adsorbent based on multi-walled carbon tubes for selective removal of perfluorooctanoic acid. Environ Sci Water Res Technol 4:689-700

3. Hao Y, Gao R, Liu D et al (2016) Selective extraction and determination of chlorogenic acid in fruit juices using hydrophilic magnetic imprinted particles. Food Chem 200:215-222

4. Ji W, Sun R, Geng Y et al (2018) Rapid, low temperature synthesis of molecularly imprinted covalent organic frameworks for the highly selective extraction of cyano pyrethroids from plant samples. Anal Chim Acta 1001:179-188

5. Liang L, Wang X, Sun Y et al (2018) Magnetic solid-phase extraction of triazine herbicides from rice using metal-organic framework MIL-101(Cr) functionalized magnetic particles. Talanta 179:512-519

6. Ma X, Meng Z, Qiu L et al (2016) Solanesol extraction from tobacco leaves by flash chromatography based on molecularly imprinted polymers. J Chromatogr, B: Anal Technol Biomed Life Sci 1020:1-5

7. Xie X, Hu Q, Ke R et al (2019) Facile preparation of photonic and magnetic dual responsive protein imprinted material for specific recognition of bovine hemoglobin. Chem Eng J 371:130-137

8. Yang J, Li Y, Wang J et al (2015) Molecularly imprinted polymer microspheres prepared by Pickering emulsion polymerization for selective solid-phase extraction of eight bisphenols from human urine samples. Anal Chim Acta 872:35-45

9. Yang F, Deng D, Dong $X$ et al (2017) Preparation of an epitopeimprinted polymer with antibody-like selectivity for beta2microglobulin and application in serum sample analysis with a facile method of on-line solid-phase extraction coupling with high performance liquid chromatography. J Chromatogr A 1494:18-26

10. Wang X, Yu S, Liu W et al (2018) Molecular imprinting based hybrid ratiometric fluorescence sensor for the visual determination of bovine hemoglobin. ACS Sens 3(2):378-385

11. GuY, Yan X, Li C et al (2016) Biomimetic sensor based on molecularly imprinted polymer with nitroreductase-like activity for metronidazole detection. Biosens Bioelectron 77:393-399

12. Sellergren B, Allender CJ (2005) Molecularly imprinted polymers: a bridge to advanced drug delivery. Adv Drug Deliv Rev 57:1733-1741

13. Zhang $\mathrm{Z}$, Wang $\mathrm{H}$, Wang $\mathrm{H}$ et al (2018) Fabrication and evaluation of molecularly imprinted magnetic nanoparticles for selective recognition and magnetic separation of lysozyme in human urine. Analyst 143:5849-5856

14. Hoshino Y, Kodama T, Okahata Y et al (2008) Peptide imprinted polymer particles: a plastic antibody. J Am Chem Soc 130:15242-15243

15. Ren K, Banaei N, Zare RN (2013) Sorting inactivated cells using cell-imprinted polymer thin films. ACS Nano 7:6031-6036

16. Wangchareansak T, Thitithanyanont A, Chuakheaw D et al (2014) A novel approach to identify molecular binding to the influenza virus $\mathrm{h} 5 \mathrm{n} 1$ : screening using molecularly imprinted polymers (MIPs). MedChemComm 5:617-621

17. Culver HR, Peppas NA (2017) Protein-imprinted polymers: the shape of things to come? Chem Mater 29(14):1-9

18. Han W, Han X, Liu ZQ et al (2020) Facile modification of protein-imprinted polydopamine coatings over nanoparticles with enhanced binding selectivity. Chem Eng J 385:123463

19. Li Q, Yang K, Liang Y et al (2014) Surface protein imprinted core-shell particles for high selective lysozyme recognition prepared by reversible addition-fragmentation chain transfer strategy. ACS Appl Mater Interfaces 6(24):21954-21960

20. Zhang $X$, Zhang N, Du C et al (2017) Preparation of magnetic epitope imprinted polymer microspheres using cyclodextrinbased ionic liquids as functional monomer for highly selective and effective enrichment of cytochrome. Chem Eng J 317:988-998

21. Zhang Z, Zhang X, Niu D et al (2017) Large-pore, silica particles with antibody-like, biorecognition sites for efficient protein separation. J Mater Chem B 5:4214-4220

22. Li L, Lu Y, Bie Z et al (2017) Berichtigung: photolithographic boronate affinity molecular imprinting: a general and facile approach for glycoprotein imprinting. Angew Chem 129:2871

23. Yan L, Wang J, Lv P et al (2017) A facile synthesis of novel three-dimensional magnetic imprinted polymers for rapid extraction of bovine serum albumin in bovine calf serum. Anal Bioanal Chem 409:3453-3463

24. Zhang $M$, Wang $Y Z$, Jia XP et al (2014) The preparation of magnetic molecularly imprinted particles for the recognition of bovine hemoglobin. Talanta 120:376-385

25. Pan XH, He XPH, Liu Z (2018) Molecularly imprinted mesoporous silica particles for specific extraction and efficient identification of Amadori compounds. Anal Chim Acta 1019:65-73

26. Anirudhan TS, Alexander S (2017) A potentiometric sensor for the trace level determination of hemoglobin in real samples using multiwalled carbon tube based molecular imprinted polymer. Eur Polym J 97:84-93

27. Kazemi A, Bahramifara N, Heydari A et al (2019) Synthesis and sustainable assessment of thiol-functionalization of magnetic graphene oxide and superparamagnetic $\mathrm{Fe}_{3} \mathrm{O}_{4} @ \mathrm{SiO}_{2}$ for $\mathrm{Hg}(\mathrm{II})$ removal from aqueous solution and petrochemical wastewater. J Taiwan Inst Chem Eng 95:78-93

28. Yin Y, Yan L, Zhang ZH et al (2015) Magnetic molecularly imprinted polydopamine nanolayer on multiwalled carbon tubes surface for protein capture. Talanta 144:671-679

29. Li WM, Chen MM, Xiong HY et al (2016) Surface protein imprinted magnetic particles for specific recognition of bovine hemoglobin. New J Chem 40:564-570

30. Wang J, Guan H, Han Q et al (2019) Fabrication of $\mathrm{Yb}^{3+}$-immobilized hydrophilic phytic acid-coated magnetic nanocomposites for the selective separation of bovine hemoglobin from bovine serum. ACS Biomater Sci Eng 5(6):2740-2749

31. Li SW, Yang KG, Deng N et al (2016) Thermoresponsive epitope surface-imprinted particles for specific capture and release of target protein from human plasma. ACS Appl Mater Interfaces 8:5747-5751 
32. Qian LW, Hu XL, Guan P et al (2015) The effectively specific recognition of bovine serum albumin imprinted silica particles by utilizing a macro molecularly functional monomer to stabilize and imprint template. Anal Chim Acta 884:97-105

33. Wang YQ, Zhang HM, Zhou QH (2009) Studies on the interaction of caffeine with bovine hemoglobin. Eur J Med Chem 44:2100-2105

34. Li X, Zhang B, Li W et al (2014) Preparation and characterization of bovine serum albumin surface-imprinted thermosensitive magnetic polymer microsphere and its application for protein recognition. Biosens Bioelectron 51:261-267

35. Jia X, Xu M, Wang Y et al (2013) Polydopamine-based molecular imprinting on silica-modified magnetic particles for recognition and separation of bovine hemoglobin. Analyst 138:651-658
36. Sun S, Chen L, Shi H et al (2014) Magnetic glass carbon electrode, modified with magnetic ferriferrous oxide particles coated with molecularly imprinted polymer films for electrochemical determination of bovine hemoglobin. J Electroanal Chem 734:18-24

Publisher's Note Springer Nature remains neutral with regard to jurisdictional claims in published maps and institutional affiliations. 